\title{
Evaluation of different screening tests for detection of Urinary Tract Infections in pregnant women attending the antenatal clinic
}

\author{
S.G. Mundhada ${ }^{1 *}$, K.V. Ingole ${ }^{2}$, M.P. Bhise ${ }^{3}$ and S.V. Shaikh ${ }^{4}$ \\ Department of Microbiology, Dr.V.M. Government medical college Solapur, Maharashtra, India \\ *Corresponding author
}

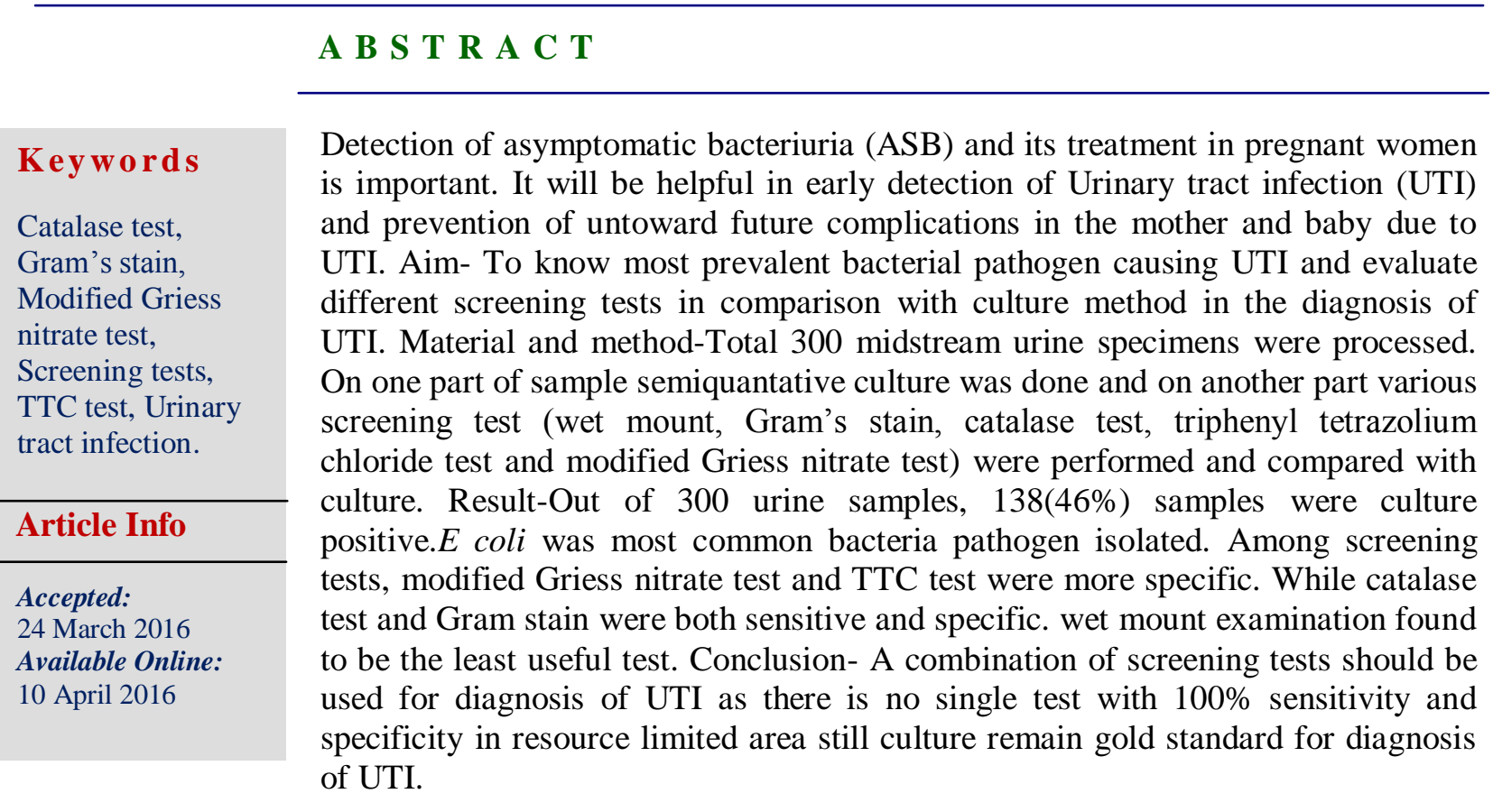

\section{Introduction}

Infection of the urinary tract (UTI) is a common problem in pregnancy due to the morphological and physiological changes that takes place in the genitourinary tract. In addition, other factors like low socio economic status, multiparity, illiteracy, medical disorders like diabetes mellitus \& sickle trait are also associated with increased incidence of UTI in pregnancy. It may be of two types, symptomatic or asymptomatic. ${ }^{1}$ Symptomatic bacteriuria poses no problems because of its easy diagnosis and treatment due to its overt symptoms but asymptomatic bacteriuria (ASB) is difficult to diagnose. Pregnant women with ASB are more likely to develop acute pyelonephritis in later pregnancy, postpartum urinary tract infection, hypertensive disease of pregnancy, anaemia, chronic renal failure, prematurity, low birth weight babies and prenatal death if untreated. Therefore to prevent untoward complications in the mother and baby that may arise due to ASB, it has been suggested 
to do routine screening for all pregnant women attending the Antenatal clinic even in the absence of symptoms. ${ }^{2,3}$

Many prompt diagnostic methods are available including screening tests like wet mount microscopy, Gram stain, catalase test, Nitrate test, Triphenyl tetrazolium chloride test, but gold standard method for diagnosis of UTI is quantitative urine culture. ${ }^{4}$ Urine culture is an expensive ,time consuming procedure and needs a well-equipped microbiology laboratory with experienced technicians. ${ }^{5}$ While On the other side, Screening tests of urine sample are designed to allow early detection of infection in the emergency department and an earlier initiation of the treatment. ${ }^{6}$ They are inexpensive, less time-consuming, easy to perform, no expertise required to perform and are useful in small laboratories having no culture facility.

Due to clinical significance of early diagnosis of UTI, different screening tests are used widely, but their performance characteristic are still questionable. ${ }^{7}$ The aims of the present study were 1.To study the prevalence of bacterial pathogens causing urinary tract infection among pregnant women2. To evaluate the accuracy of different screening test for diagnosis of UTI, keeping semi quantitative culture as the gold standard.

\section{Materials and Methods}

The study was carried out in the Department of microbiology, Dr. V.M. government medical college Solapur, Maharashtra in women coming for their antenatal check-up in obstetric OPD. They were asked to collect clean catch midstream urine sample in a sterile wide mouth container after proper explanation. Total 300 urine sample were collected and each of them was divided into 2 parts - one for culture and the other for screening tests.

Urine was cultured on Blood and MacConkey agar using a calibrated loop of $4 \mathrm{~mm}$ in diameter. After overnight incubation at $37{ }^{\circ} \mathrm{Cfor} 18$ to 24 hours on, if bacterial counts $\geq 10^{5}$ per $\mathrm{ml}$ were seen, they were taken as positive in asymptomatic women. (as per Kass concept of significant bacteriuria). ${ }^{8}$ The isolates were identified by colony morphology, gram stain and biochemical reactions. ${ }^{9}$ The antibiotic susceptibility testing (AST) was done by Kirby-Bauer disc diffusion method on Muller Hinton agar for following antibiotics - Norfloxacin $(10 \mu \mathrm{g})$, Nitrofurantoin (300 $\mu \mathrm{g})$, Cephalexin $(30 \mu \mathrm{g})$, Amoxicillin (25 $\mu \mathrm{g})$, Gentamicin $(10 \mu \mathrm{g})$ and ciprofloxacin (5ug) (Hi-media Mumbai). ${ }^{10}$ Following screening tests were done.

1. Direct wet mount ${ }^{8}:$ Pus cells/high power field (hpf) were counted. About 20 fields were searched. Finding $>1$ pus cell/ 7 hpf indicates significant pyuria. Apart from pus cells, RBC, any casts, bacteria, yeast cells were also noted.

2. Gram Staining ${ }^{8}$ : The presence of $\geq 1$ bacteria/Oil immersion field in 20 fields correlated with the diagnosis of significant bacteriuria of $\geq 10^{5} \mathrm{CFU} / \mathrm{ml}$ of urine.

3. Catalase test ${ }^{11}$ : Four drops of $10 \%$ hydrogen peroxide were added in $2 \mathrm{ml}$ of urine in the test tube. The mixture was shaken gently for 5 seconds. Formation of effervescence to form a complete ring or layer on the surface of the liquid within 1 to 2 minutes was taken as positive test. Positive control- Staphylococcus aureusand Negative control - Enterococci species.

4. Triphenyl tetrazolium chloride (TTC) test

${ }^{12}$ : $2 \mathrm{ml}$ of urine was taken in a sterile test 
tube and $0.5 \mathrm{ml}$ of working triphenyl tetrazolium chloride reagent was added. This mixture was incubated at $37^{0} \mathrm{C}$ for 4 hours. Formation of red precipitate indicated a positive test.

5. Modified Griess Nitrite Test ${ }^{13}: 8 \mathrm{ml}$. of urine was taken in a test tube and centrifuged this for 15 minutes. The supernatant was decanted. To the precipitate, $0.5 \mathrm{ml}$. of a $10 \%$ solution of potassium nitrate was added. This was incubated for one and half hour at room temperature. Then, $1 \mathrm{ml}$ of the Griess reagent $(0.5 \mathrm{ml}$ of solution A: Sulphanilic acid $+0.5 \mathrm{ml}$ of solution $\mathrm{B}: \alpha$-naphthylamine) was added to it. The development of a pink or a red colour in a matter of seconds was considered to be a positive test. Asepsis was strictly observed. Positive control E.coliand Negative control - Enterococci species.

\section{Results and Discussion}

Out of 300 samples taken from pregnant females $138(46 \%)$ showed significant bacteriuria by the semiquantative culture method. Most common organisms isolated was - E.coli ( 69.56\%) followed by Klebsiella species (10.86\%), Proteus species ( 5.07\%), Pseudomonas aeruginosa (5.07 $\%)$, Staphylococcus aureus (4.34\%), Enterococci species $(2.89 \%) \quad$ and Acinetobacter species (2.17\%).For all the organisms isolated (Gram positive and Gram negative), nitrofurantoin was the most sensitive drug (94.20\%), followed by cephalexin $(89.85 \%)$, amoxicillin $(88.40 \%)$, norfloxacin $(86.95 \%)$,gentamicin $(78.98 \%)$ and ciprofloxacin(71.01\%). Evaluation of various screening tests in relation to the culture is as given below. (Table II and Table III).

The global prevalence of bacteriuria in pregnancy varies from $4 \%$ to $23.9 \%$ in various studies. ${ }^{14}$ The prevalence of ASB in the present study was $46 \%$ which correlates with the studies done by Rani et al $(51.2 \%){ }^{15}$ This high prevalence was attributed to their low socioeconomic status, lack of personal and environmental hygiene. The diagnosis of UTI is currently based on concept of quantitative bacteriuria, but for mass detection of UTI especially in risk groups like diabetics, antenatal cases and children in health surveys, reliable screening method is essential. The purpose of urine screening is to eliminate those specimens that do not contain significant number of bacteria.

In present study, sensitivity and specificity of wet mount (pyuria) was $63.04 \%$ and $86.42 \%$ respectively. Similar results were noted by Siddiqui et al. ${ }^{16}$ There were 38 samples in which pus cell were found in urine but there was no significant growth on culture media indicating either sterile pyuria pointing towards the noncultural organisms like Chlamydia as the causative agent or disintegration of the pus cells due to the presence of Proteus, Klebsiella and Pseudomonas in alkaline urine. ${ }^{15}$ Also the positive predictive value was less i.e. $69.60 \%$ making this test less useful in the diagnosis of urinary tract infection. According to Kass ${ }^{17}$, there is a fair approximation between the presence of bacteria in direct smear and bacteriological counts. In present study we also observed similar correlation,out of 138 samples positive on culture, 108 had shown presence of $\geq 1$ bacteria/Oil immersion field in 20 fields on Gram stain suggestive of significant bacteriuria. Sensitivity and specificity of Gram stain was $78.26 \%$ and $88.89 \%$ respectively which was comparable to results noted by Siddique et $\mathrm{al}^{16}$ and Yap Hui kim et $\mathrm{al}^{18}$. 
Table.1 Frequency of Organisms Isolated from Urine Sample on Culture $(\mathrm{N}=138)$

\begin{tabular}{|l|l|}
\hline Organism isolated & Number $(\%)$ \\
\hline E.coli & $96(69.56)$ \\
\hline Klebsiella species & $15(10.86)$ \\
\hline Proteus species & $7(5.07)$ \\
\hline $\begin{array}{l}\text { Pseudomonas } \\
\text { aeruginosa }\end{array}$ & $7(5.07)$ \\
\hline $\begin{array}{l}\text { Staphylococcus } \\
\text { aureus }\end{array}$ & $6(4.34)$ \\
\hline Enterococci species & $4(2.89)$ \\
\hline $\begin{array}{l}\text { Acinetobacter } \\
\text { species }\end{array}$ & $3(2.17)$ \\
\hline
\end{tabular}

Table.2 Statistical Analysis of Various Screening Tests with Respect to Culture. ( $\mathrm{n}=138)$

\begin{tabular}{|l|l|l|l|l|}
\hline Tests & $\begin{array}{l}\text { True positive } \\
\text { (culture is } \\
\text { positive } \\
\text { screening test } \\
\text { positive) }\end{array}$ & $\begin{array}{l}\text { False positive } \\
\text { (culture is } \\
\text { negative } \\
\text { screening test } \\
\text { positive) }\end{array}$ & $\begin{array}{l}\text { False negative } \\
\text { (culture is } \\
\text { positive } \\
\text { screening tests } \\
\text { negative) }\end{array}$ & $\begin{array}{l}\text { True negative } \\
\text { culture negative } \\
\text { screening test } \\
\text { negative) }\end{array}$ \\
\hline Wet mount & 87 & 38 & 51 & 124 \\
\hline Gram stain & 108 & 18 & 30 & 144 \\
\hline Catalase test & 131 & 15 & 7 & 147 \\
\hline TTC test & 119 & 7 & 19 & 155 \\
\hline $\begin{array}{l}\text { Modified Griess } \\
\text { Nitrite test }\end{array}$ & 125 & 9 & 13 & 153 \\
\hline
\end{tabular}

Table 3 Sensitivity, Specificity and Predictive Value of Various Screening Tests

\begin{tabular}{|l|c|c|c|c|}
\hline \multicolumn{1}{|c|}{ Tests } & $\begin{array}{l}\text { Sensitivity } \\
(\mathbf{\%})\end{array}$ & $\begin{array}{l}\text { Specificity } \\
(\mathbf{\%})\end{array}$ & $\begin{array}{l}\text { Positive predictive } \\
\text { value (\%) }\end{array}$ & $\begin{array}{l}\text { Negative predictive } \\
\text { value (\%) }\end{array}$ \\
\hline Wet mount & 63.04 & 86.42 & 69.60 & 70.85 \\
\hline Gram stain & 78.26 & 88.89 & 85.71 & 82.76 \\
\hline Catalase test & 94.93 & 90.74 & 89.73 & 95.45 \\
\hline TTC test & 86.23 & 95.67 & 94.44 & 89.08 \\
\hline $\begin{array}{l}\text { Modified Griess } \\
\text { Nitrite test }\end{array}$ & 86.95 & 94.44 & 93.02 & 89.47 \\
\hline
\end{tabular}

In this study, Catalase test was found to be 94.94\% sensitive and $90.74 \%$ specific. Similar results was noted by Siddique et al. ${ }^{16}$ There were 15 samples which were catalase positive but did not show any growth on culture media which might be due to haematuria in the patients. By Triphenyl Tetrazolium chloride(TTC) test we obtained $86.23 \%$ sensitivity and $95.67 \%$
specificity.Other worker like Agrawal et al $(81.3 \%)^{19}$ and Wagle et al $(86.9 \%)^{20}$ also noted similar sensitivity of test but low specificity compared to our study. According to Hinton et $\mathrm{al}^{12}$, the frequency of positive TTC test was directly related to number of bacteria per $\mathrm{ml}$ of samples and not by other non-specific factors like glucose, ketones, urobilinogen, cast, 
crystals, number of pus cells, RBCs in sample. But main drawback of test is that it was not well standardized because different bacteria respire at different rates. Specificity (94.44\%) of Modified Griess nitrate test was more than Sensitivity $(86.95 \%)$ in present study so test is more useful in rolling out UTI in patients. Similar finding were noted by Rani et $\mathrm{al}^{15}$ and Siddique et $\mathrm{al}^{16}$, while in contrast result was noted by Najeeb et al. ${ }^{4}$ Total 13 false negative samples were noted as nitrate test does not detect organisms unable to reduce nitrate to nitrite, such as Enterococci, Staphylococci species, Acinetobacter etc. ${ }^{21}$

There is variation in result from different studies while comparing performance of different screening tests, it may be because of different sample population in different studies like high risk population, Gender, Children or because of variation in procedure while performing tests.

Based on this study, a combination of screening tests should be used for diagnosis of UTI as there is no single test with $100 \%$ sensitivity and specificity. The selection of screening tests will be depend on the facilities available and patient load at the given laboratory. Screening tests are suitable for screening large population at high risk in resource limited area depending on that empirical treatment can be given to patient. But laboratories were adequate culture facilities are available, it remains the gold standard method for detection of urinary tract infection.

\section{References}

1. Hankins GD, Whalley PJ. Acute urinary tract infections in pregnancy. ClinObstetGynaecol 1985;28:266-78.

2. Prasanna B,Naimisha M, Swathi K, Shaik MV. Prevalence of Asymptomatic
Bacteriuria in Pregnant Women, Isolates and their Culture Sensitivity Pattern. Int.J.Curr.Microbiol.App.Sci 2015;4(8): 28-35

3. Jain SA, Pandya JM, Mehta SJ, Jain AG, Kikani KM, Pandya MR. Evaluation of asymptomatic bacteriuria in antenatal women at CU Shah Medical College \& Hospital, Surendranagar, Gujarat. Int J Med Sci Public Health 2013; 2:1021-23.

4. Najeeb S, Munir T, Rehman S, Hafiz A, Gilani M, Latif M. Comparison of Urine Dipstick Test with Conventional Urine Culture in Diagnosis of Urinary Tract Infection. Journal of the College of Physicians and Surgeons Pakistan 2015;Vol. 25(2): 108-10

5. Hajar F, Taleb M, Aoun B, Shatila A. Dipstick urine analysis screening among asymptomatic school children. North Am J Med Sci 2011; 3:179-84.

6. Thuo N, Ohuma E, Karisa J, Talbert A, Berkley JA, Maitland K. The prognostic value of dipstick urinalysis in children admitted to hospital with severe malnutrition. Arch Dis Childhood 2010; 95:422-6.

7. Mori R, Yonemoto $\mathrm{N}$, Fitzgerald A, Tullus K, Verrier-Jones K, Lakhanpaul M. Diagnostic performance of urine dipstick testing in children with suspected UTI: a systematic review of relationship with age and comparison with microscopy. ActaPaediatrica 2010; 99:581-4.

8. Collee JG, Miles RS, Watt B. Laboratory strategy in the diagnosis of infective syndrome. In: Colle JG, Fraser AG, Marimon BP, Simmons A, editors. Mackie and McCartney Practical Medical Microbiology. 14th ed. Edinburg: Elsevier Churchill Livingstone; 2006. p.84-90.

9. Forbes BA, Sahm DF, Weissfeld AS. Overview of bacterial identification 
methods and strategies. Bailey and Scott's Diagnostic Microbiology. 12th ed. Missouri: Mosby Elsevier; 2007. p. 218-47.

10. Performance Standards for Antimicrobial Susceptibility Testing; Twenty-fifth Informational Supplement. CLSI document M100-S25. Wayne, PA: Clinical and Laboratory Standards Institute; 2015.

11. Palmer LS, Richards I, Kaplan W. Clinical evaluation of a rapid diagnostic screen (Uriscreen) for bacteriuria in children. J Urol 1997; 157:654-657.

12. Hinton NA, Hoeve E. The Detection of Significant Bacteriuria: An Assessment of the Triphenyltetrazolium Chloride Reduction Test. Canad. Med. Ass. J.1965;Vo193:639-42.

13. Srihari A ,Beeregowda YC, Vishnu Vardhan Reddy T. A comparitive study of griess nitrate test and urinary culture in detection of asymtomatic bacteriuria in children. Int J Biol Med Res. 2012; 3(1): 1439-41.

14. Ansari HQF, Rajkumari A. Prevalence of asymptomatic bacteriuria and associated risk factors among antenatal women attending a tertiary care hospital. J Med Allied Sci. 2001; 1(2): 74-78.

15. Rani UV, Sudhindra KS, Grace NB, Pradeep G, Kapoor A, Shilpa L. Evaluation of various screening tests for detection of Urinary tract infections. Journal of Biomedical and
Pharmaceutical Research 3 (2) 2014, 15-20.

16. Siddiqui SM, Deshmukh AB, Afreen $\mathrm{U}$, Bhanap PL. Evaluation of screening tests to detect asymptomatic bacteriuria in obstretic patients at Noor Hospital, Warudi, Jalna. MedPulse - International Medical Journal October 2014; 1(10): 6 23-626.

17. Kass EH. Asymptomatic infections of the urinary tract. Trans. Assoc. Am. Physicians1956; 69:56-63.

18. Yap Hui Kim, Belinda Murugasu Urinary tract infection in children Paediatrics Shared care programme. National university of health Bulletin 6 september1998;1-9.

19. Agrawal SK, Das R, Goel M, Kumar M. Tetrazolium reduction test in diagnosis of urinary tract infections. Indian I PatholMicrobiol 1986;29:61-65.

20. Wagle N, Vaidya A, Joshi S, Merchant S. Triphenyl Tetrazolium Chloride (TTC) Dye Test for Quick Diagnosis of Urinary Tract Infection. Indian Journal of Pediatrics1989 sept;Vol56(5):635-38.

21. RangaiahagariA, Nyirabanzi J , Uwizeyimana JP, NgogaE, Wane J.Comparison of urine culture and urine dipstick nitrite test in diagnosis of Urinary Tract Infection. Rwanda Medical Journal2015; Vol.72 (1):5-7.

\section{How to cite this article:}

Mundhada, S.G., K.V. Ingole, M.P. Bhise and Shaikh, S.V. 2016. Evaluation of different screening tests for detection of Urinary Tract Infections in pregnant women attending the antenatal clinic. Int.J.Curr.Microbiol.App.Sci. 5(4): 772-777. doi: http://dx.doi.org/10.20546/ijcmas.2016.504.088 